\title{
Metabolic Inhibition Potentiates Oxidant Injury
}

\author{
RalPh E. Delius, M.D., AND Daniel B. Hinshaw, M.D. ${ }^{1}$ \\ Surgical Service, Ann Arbor Veterans Administration Medical Center, Department of Surgery, \\ University of Michigan, Ann Arbor, Michigan 48105
}

Presented at the Annual Meeting of the Association for Academic Surgery, Houston, Texas, November 14-17, 1990

Toxic oxygen species have been implicated as important mediators of injury after reperfusion of an ischemic organ. The aim of this study was to determine if prior metabolic inhibition, such as that which occurs during ischemia, potentiates oxidant injury in vitro. Bovine pulmonary artery endothelial cells were metabolically inhibited for various periods of time with or without the mitochondrial inhibitor oligomycin $(650$ $\mathrm{n} \boldsymbol{M}$ ). The cells were rescued from metabolic inhibition by a wash step and subsequent addition of $5.5 \mathrm{mM}$ glucose. At the same time that metabolic inhibition was relieved the cells were subjected to doses of $\mathrm{H}_{2} \mathrm{O}_{2}$ ranging from 0 to $100 \mu M$. ATP levels were monitored over a 2-hr time course after rescue from metabolic inhibition by the luciferin-luciferase assay. Cell viability at $2 \mathrm{hr}$ after relief of metabolic inhibition was assessed by trypan blue exclusion. Intracellular pH during metabolic inhibition was determined with the fluorescent dye $2^{\prime}, 7^{\prime}$-bis-(2-carboxyethyl)-5(and-6) carboxyfluorescein tetraacetomethoxymethyl ester. $\mathrm{H}_{2} \mathrm{O}_{2}$ consumption, a measure of $\mathrm{H}_{2} \mathrm{O}_{2}$ scavenging capability, was determined by a fluorescent assay. The viability and ATP levels of cells not subjected to metabolic inhibition were unaffected by these low concentrations of $\mathrm{H}_{2} \mathrm{O}_{2}$. Cells metabolically inhibited with glucose depletion and oligomycin were exquisitely sensitive to $\mathrm{H}_{2} \mathrm{O}_{2}$. Cells that were only deprived of glucose demonstrated no potentiation of injury, while cells subjected to mitochondrial inhibition with oligomycin alone also showed significant potentiation of oxidant injury. $\mathrm{H}_{2} \mathrm{O}_{2}$ consumption was not affected by metabolic inhibition. Conditions associated with mitochondrial inhibition consistently resulted in a decrease in intracellular pH. These experiments suggest that a synergism exists between metabolic inhibition and subsequent oxidant exposure. This synergism is dependent on inhibition of mitochondrial function but is independent of ATP levels. Intracellular acidosis correlated well with condi-

\footnotetext{
${ }^{1}$ To whom reprint requests should be addressed at Surgical Service, VA Medical Center, 2215 Fuller Rd., Ann Arbor, MI 48105.
}

tions which potentiated oxidant injury. 1991 Academic Press, Inc.

\section{INTRODUCTION}

Evidence has accumulated that oxygen free radicals may be important mediators of injury after reperfusion of an ischemic organ. A variety of biochemical perturbations have been shown to be induced by oxidant exposure, including inhibition of the glycolytic enzyme glyceraldehyde-3-phosphate dehydrogenase [1], loss of adenosine triphosphate (ATP) synthesis [2], DNA injury [3], pyridine nucleotide depletion [4], cytoskeletal alterations [5], and elevation of intracellular calcium [6]. Commonly implicated sources of toxic oxygen species during reperfusion include neutrophils [7] and xanthine oxidase [8]. However, oxidants are ubiquitous and even normal cellular functions such as mitochondrial respiration can generate small amounts of potentially toxic oxidants. In response to this, virtually all eucaryotic cells have developed extensive antioxidant defenses as well as mechanisms to repair oxidant injury once it has occurred. The effectiveness of these antioxidant mechanisms has been demonstrated by several prior studies of oxidant-mediated endothelial cell injury, in which high micromolar or even millimolar concentrations of $\mathrm{H}_{2} \mathrm{O}_{2}$ were required to generate significant short-term cell injury $[5,9]$.

Inhibition of cellular ATP synthesis by substrate (i.e., glucose) depletion and mitochondrial inhibition due to oxygen deprivation are major biochemical consequences of acute ischemia following cessation of blood flow. Ischemic conditions also lead to additional changes in the intracellular milieu, including acidosis [10], microfilament disruption [11], and possibly elevation of intracellular calcium [12]. Some of these changes, such as intracellular acidosis, have been found to be protective against ischemic injury $[10,13]$. However, the possibility that changes in intracellular homeostasis resulting from 
ischemia may render cells particularly vulnerable to an oxidant injury has not been extensively studied. In a study by Ferrari et al. [14], rabbit hearts subjected to severe ischemia were found to have significantly compromised defenses against oxidant injury. 'The conditions under which cells are exposed to an oxidant challenge may be relevant to the pathophysiology of oxidant injury. The aim of this study was to determine if a synergism exists between the metabolic inhibition which occurs under ischemic conditions and subsequent oxidant exposure. A "chemical ischemia" model was used to rapidly and reliably decrease ATP levels in order to mimic ischemia in vitro. This model, which utilizes glucose deprivation and a mitochondrial inhibitor, has been previously described $[11,15]$ and avoids the elaborate technical requirements for maintaining strict anaerobiosis in cell suspensions.

\section{METHODS AND MATERIALS}

\section{Cells and Culture}

Bovine pulmonary artery endothelial cells (No. AG 2791A) from the National Institute of Aging, Aging Cell Culture Repository (Camden, $\mathrm{NJ}$ ) were cultured to confluence in $150-\mathrm{cm}^{2}$ flasks (Corning). They were cultured in media that consisted of RPMI 1640 supplemented with $10 \%$ fetal bovine serum (Whittaker, M. A. Bioproducts), $2 \mathrm{mM}$ glutamine (GIBCO), $10 \mathrm{~m} M$ Hepes (Whittaker, M. A. Bioproducts), $100 \mathrm{u} / \mathrm{ml}$ penicillin, and 100 $\mu \mathrm{g} / \mathrm{ml}$ streptomycin (GIBCO). Cells were passaged after a 10 - to 15 -min exposure to trypsin $(0.05 \%)$ and ethylenediaminetetracetic acid $(0.02 \%$, Sigma, St. Louis, MO). Cells from passages 2-12 were used for these experiments.

For experiments the cells were suspended at a concentration of $2 \times 10^{6}$ cells $/ \mathrm{ml}$ in modified Gey's buffer containing $147 \mathrm{mM} \mathrm{NaCl}, 5 \mathrm{mM} \mathrm{KCl}, 1.9 \mathrm{mM} \mathrm{KH} \mathrm{KO}_{2} \mathrm{PO}_{4}, 1.1$ $\mathrm{mM} \mathrm{Na}_{2} \mathrm{HPO}_{4}, 0.3 \mathrm{mM} \mathrm{MgSO}_{4}, 1 \mathrm{mM} \mathrm{MgCl}_{2}, 5.5 \mathrm{mM}$ glucose, $10 \mathrm{mM}$ 4-(2-hydroxyethyl)-1-piperazineethanesulfonic acid (Hepes), and $1.5 \mathrm{mM} \mathrm{CaCl}{ }_{2}$. In selected experiments glucose was deleted from the buffer.

\section{ATP Measurements [16]}

At appropriate time points, $100 \mu \mathrm{l}$ of cell suspension was added to $2.0 \mathrm{ml}$ of buffer containing $10 \mathrm{mM}$

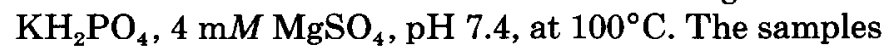
were placed in ice after $4 \mathrm{~min}$. To complete the assay, $0.75 \mathrm{ml}$ of sample was added to $1.5 \mathrm{ml}$ of $50 \mathrm{mM} \mathrm{NaAsO}{ }_{4}$, $20 \mathrm{mM} \mathrm{MgSO}{ }_{4}, \mathrm{pH}$ 7.40. Assays were performed on 1-ml aliquots. The luciferin-luciferase (Sigma No. L0633) was reconstituted at $40 \mathrm{mg} / \mathrm{ml}$ in sterile water and diluted 1:50 in a buffer containing $1 \%$ bovine serum albumin, $20 \mathrm{~m} M$ glycine, and $2 \mathrm{mM}$ ethylenediaminetetrace- tic acid, pH 8.0. Sixty microliters of luciferin-luciferase was added to $1 \mathrm{ml}$ aliquot in an LKB Model 1251 automated luminometer. A standard curve was prepared with ATP concentrations ranging from $5 \times 10^{-10}$ to 1 $\times 10^{-8} M$.

\section{Trypan Blue Exclusion}

Cellular viability was assessed by the ability of the cells to exclude trypan blue. Fifty microliters of cell suspension was incubated for a brief period of time with 12 $\mu \mathrm{l} 0.1 \%$ trypan blue in $0.9 \% \mathrm{NaCl}$ (final concentration approximately $0.02 \%$ ). The number of cells excluding trypan blue out of 100 cells counted on a hemocytometer was equivalent to the percentage of viable cells.

\section{Intracellular $p H$ Measurements}

Endothelial cells were incubated at $1 \times 10^{7}$ cells $/ \mathrm{ml}$ with 2',7'-bis-(2-carboxyethyl)-5 (and -6) carboxyfluorescein tetraacetoxymethyl ester (BCECF-AM) at $5 \mu M$ (Molecular Probes, Inc., Junction City, OR) for $30 \mathrm{~min}$ at $37^{\circ} \mathrm{C}$. At the end of this period, the cells were pelleted and resuspended at $2 \times 10^{6} \mathrm{cells} / \mathrm{ml}$ in modified Gey's buffer as described earlier. Measurements were performed in plastic 3-ml cuvettes containing a magnetic starhead stir bar. Fluorescence intensities were measured at $37^{\circ} \mathrm{C}$ in a sample of washed cells in an SLM 8000 spectrophotometer. Excitation and emission intensities were 490 and $520 \mathrm{~nm}$, respectively. Intracellular $\mathrm{pH}$ was estimated by the method of Hyslop et al. [1]. Cells were permeabilized with $0.1 \%$ digitonin after initial fluorescence readings were obtained.

\section{$\mathrm{H}_{2} \mathrm{O}_{2}$ Consumption}

To assess the overall status of cellular antioxidant defenses, the rate of $\mathrm{H}_{2} \mathrm{O}_{2}$ consumption was determined by the technique of Hyslop and Sklar [17]. Briefly, the nonfluorescent substrate $p$-hydroxyphenylacetate (PHPA, Sigma Chemical Co., St. Louis, MO) is oxidized to the stable fluorescent product $2,2^{\prime}$-dihydroxybiphenyl-5, $5^{\prime}$ diacetate (PHPA) $)_{2}$ by the enzymatic reduction of $\mathrm{H}_{2} \mathrm{O}_{2}$ by horseradish peroxidase (Type IV, Sigma). After cells

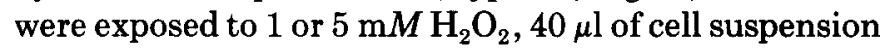
was added to $45 \mu \mathrm{l}$ of PHPA and $20 \mu \mathrm{l}$ of horseradish peroxidase in $2 \mathrm{ml}$ of modified Gey's buffer. Assays were performed in plastic 3-ml cuvettes containing a magnetic starhead stir bar. The samples were placed in a stirred thermostated sample chamber of an SLM series 8000 spectrophotofluorimeter at $37^{\circ} \mathrm{C}$. Excitation and emission intensities were 323 and $400 \mathrm{~nm}$, respectively.

\section{Statistics}

All data represent at least four experiments and are expressed as means \pm SD unless otherwise indicated. Cell viability data and $\mathrm{pH}$ measurements were analyzed by paired $t$ tests. ATP measurements were analyzed by 
repeated measures analysis of variance. A probability of $<0.05$ was considered statistically significant.

\section{RESULTS}

\section{Description of Model}

Acute ischemia following interruption of blood flow leads to inhibition of ATP synthesis by depletion of glycolytic substrate and suppression of mitochondrial respiration due to low oxygen tension within the cell. A "chemical ischemia" model that has previously been described was used to mimic ischemic conditions in vitro [11]. This model uses glucose-free buffer and a mitochondrial inhibitor ( $650 \mathrm{nM}$ oligomycin or $4 \mathrm{mM} \mathrm{KCN}$ ) to simulate ischemia. The dose of oligomycin was derived from previous studies [2]. The KCN dose was determined by a dose-response curve in which ATP synthesis was inhibited to the same extent as in the oligomycin model (data not shown). This chemical ischemia model has been shown to reproducibly decrease intracellular ATP levels and avoids the technical difficulties of maintaining strict anaerobic conditions in cell suspension. To mimic reperfusion, metabolic inhibition was relieved by removing the mitochondrial inhibitor in a rapid wash step and adding $5.5 \mathrm{mM}$ glucose to the buffer. Simultaneously, the cells were exposed $0,25,50$, or 100 $\mu M \mathrm{H}_{2} \mathrm{O}_{2}$. Recovery of ATP levels was followed during a subsequent 2 - $\mathrm{hr}$ time course. Cell viability was assessed by trypan blue exclusion $2 \mathrm{hr}$ after the end of metabolic inhibition and addition of $\mathrm{H}_{2} \mathrm{O}_{2}$.

\section{Effect of Glucose Depletion and Mitochondrial Inhibition}

Two hours of chemical ischemia induced by glucose deprivation and mitochondrial inhibition with oligomycin resulted in an $86.5 \%$ decrease in ATP levels (Fig. 1b). Cell viability was modestly affected during this period of metabolic inhibition, with $91.3 \pm 3.1 \%$ of the cells viable prior to metabolic inhibition and $85.5 \pm 6.0 \%$ viable after $2 \mathrm{hr}$ of metabolic inhibition $(P=0.02)$. Cells that were allowed to recover after metabolic inhibition without simultaneous exposure to $\mathrm{H}_{2} \mathrm{O}_{2}$ restored their ATP levels to $43 \%$ of initial values by $2 \mathrm{hr}$ after recovery was initiated (Fig. 2). The viability of these cells after this time period of recovery $(86.8 \pm 3.1 \%)$ was similar to the viability of the cells after the period of metabolic inhibition $(85.5 \pm 6.0 \%, P>0.05)$. Compared to cells which were not subjected to $\mathrm{H}_{2} \mathrm{O}_{2}$, cells injured with 25,50 , or $100 \mu M \mathrm{H}_{2} \mathrm{O}_{2}$ did not significantly recover their ATP levels $(P<0.05)$. A significant decrease $(P<0.05)$ in cell viability was also noted for each concentration of oxidant (Fig. 2). In control cells that were incubated in buffer for $2 \mathrm{hr}$ but not subjected to metabolic inhibition, these same $\mathrm{H}_{2} \mathrm{O}_{2}$ concentrations did not have any significant effect on ATP levels or cell viability (Fig. 3).

\section{Effect of Glucose Depletion Alone}

To determine the effect of substrate depletion alone on the susceptibility of cells to an oxidant challenge, cells were incubated in glucose-free buffer for $4 \mathrm{hr}$, since this length of time was required before a significant decrease in ATP levels was apparent. No mitochondrial inhibitors were used. Cells were washed with a buffer containing glucose and simultaneously injured with $\mathrm{H}_{2} \mathrm{O}_{2}$ as described above. ATP levels dropped by $68 \%(P$ $<0.05$ ) during the period of substrate depletion (Fig. 1c). $\mathrm{H}_{2} \mathrm{O}_{2}$ concentrations of 25,50 , and $100 \mu M$ did not significantly change ATP levels or cell viability compared to cells allowed to recover without an oxidant challenge (Fig. 4). This suggested that a period of prior substrate depletion alone was probably not sufficient to render cells more vulnerable to an oxidant attack.

\section{Effect of Mitochondrial Inhibition Alone}

To assess whether mitochondrial inhibition alone would produce similar effects, cells were incubated for 2 hr with oligomycin in a buffer containing glucose. During this time period ATP levels dropped by $56 \%$ ( $P$ $=0.04$ ), which was similar to substrate depletion alone but not to the same degree as combined substrate depletion and mitochondrial inhibition (Fig. 1d). After $2 \mathrm{hr}$ the cells were washed with buffer and exposed to the same concentrations of $\mathrm{H}_{2} \mathrm{O}_{2}$ mentioned earlier. The cells injured with 25,50 , or $100 \mu M \mathrm{H}_{2} \mathrm{O}_{2}$ had significantly lower levels of ATP and number of viable cells 2 hr after exposure to $\mathrm{H}_{2} \mathrm{O}_{2}$ compared to similarly inhibited cells which were not injured with $\mathrm{H}_{2} \mathrm{O}_{2}$ (Fig. 5). These results suggested that mitochondrial inhibition could be a key factor in determining the sensitivity of cells to low concentrations of $\mathrm{H}_{2} \mathrm{O}_{2}$.

\section{Effect of ATP Depletion on Cell Susceptibility to Oxidants}

To determine if ATP depletion is an important factor in the synergism between mitochondrial inhibition and oxidant injury, cells were inhibited for 15 min with oligomycin in buffer containing glucose. ATP levels did not drop significantly $(P>0.05)$ during this short incubation period (Fig. 1e). Subsequent washing and injury with 25,50 , or $100 \mu M \mathrm{H}_{2} \mathrm{O}_{2}$ revealed that ATP levels and cell viability were significantly affected $(P<0.05)$ compared to those cells not subjected to $\mathrm{H}_{2} \mathrm{O}_{2}$ (Fig. 6). These findings underscored the concept that mitochondrial inhibition appeared to be an important factor in determining cell sensitivity to low concentrations of oxidants. Furthermore, this experiment also suggested that ATP depletion in itself was not a major determinant of the ability of a cell to withstand an oxidant injury.

\section{Effect of Glucose Depletion and Mitochondrial Inhibition with $K C N$}

Another mitochondrial inhibitor (4 $\mathrm{mM} \mathrm{KCN})$ was used to determine if mitochondrial inhibition via a different mechanism would produce similar effects. Cells were incubated in a glucose-free buffer with $4 \mathrm{mM} \mathrm{KCN}$ for $2 \mathrm{hr}$ and were then washed with buffer and simultaneously exposed to $0,25,50$, or $100 \mu M \mathrm{H}_{2} \mathrm{O}_{2}$. During the period of metabolic inhibition ATP levels dropped $96 \%$ (Fig. 1f), while cell viability was only modestly affected 


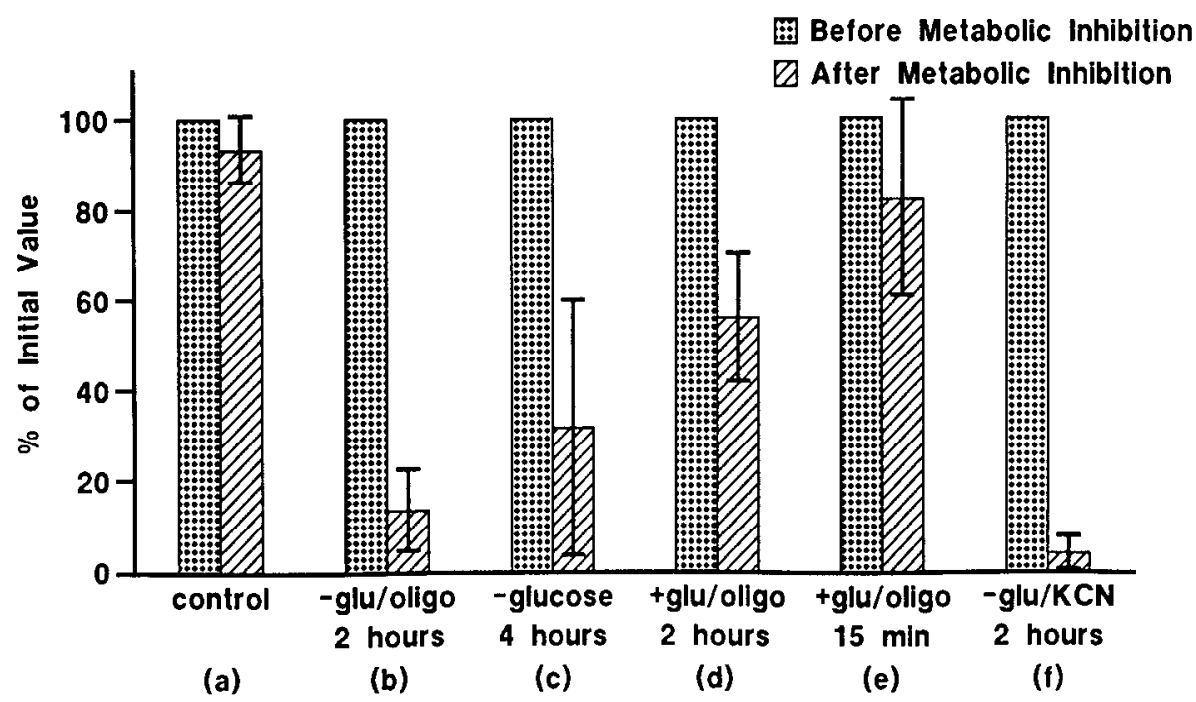

FIG. 1. ATP levels before and after metabolic inhibition. Conditions during metabolic inhibition are described along the $x$ axis. Conditions $\mathrm{b}, \mathrm{c}, \mathrm{d}$, and $\mathrm{f}$ were significantly different $(P<0.05)$ from initial values, while a and e were not significantly different. There were no significant differences between $c$ and $d$ or between $b$ and $f$.

$(89.6 \% \pm 2.3$ before inhibition, $85.8 \pm 3.3$ after inhibition, $P=0.03$ ). In contrast to cells incubated for $2 \mathrm{hr}$ with oligomycin in a glucose-free buffer, the ATP levels of cells recovering from inhibition with $\mathrm{KCN}$ were not significantly affected by low doses of $\mathrm{H}_{2} \mathrm{O}_{2}$. Cells subjected to chemical ischemia with $\mathrm{KCN}$ and glucose deprivation and exposed to 25,50 , or $100 \mu M \mathrm{H}_{2} \mathrm{O}_{2}$ recovered their ATP levels to the same extent as cells not subjected to $\mathrm{H}_{2} \mathrm{O}_{2}$ (Fig. 7). Cell viability, however, was significantly affected $(P<0.05)$ by the low doses of $\mathrm{H}_{2} \mathrm{O}_{2}$ and was similar to cells inhibited with oligomycin and glucose deprivation. Although KCN-treated cells showed significantly greater recovery of their ATP lev- els after rescue from metabolic inhibition, this did not result in better cell survival.

\section{Correlation of Mitochondrial Inhibition with Intracellular $\mathrm{pH}$ Changes}

Inhibition of mitochondrial function appeared to be an important determinant of increased cellular vulnerability to low concentrations of $\mathrm{H}_{2} \mathrm{O}_{2}$. Furthermore, the susceptibility to oxidant injury mediated by mitochondrial inhibition did not seem to be dependent on intracellular ATP levels and was also apparent within 15 min of inhibition. Since chemical ischemia with mitochon-

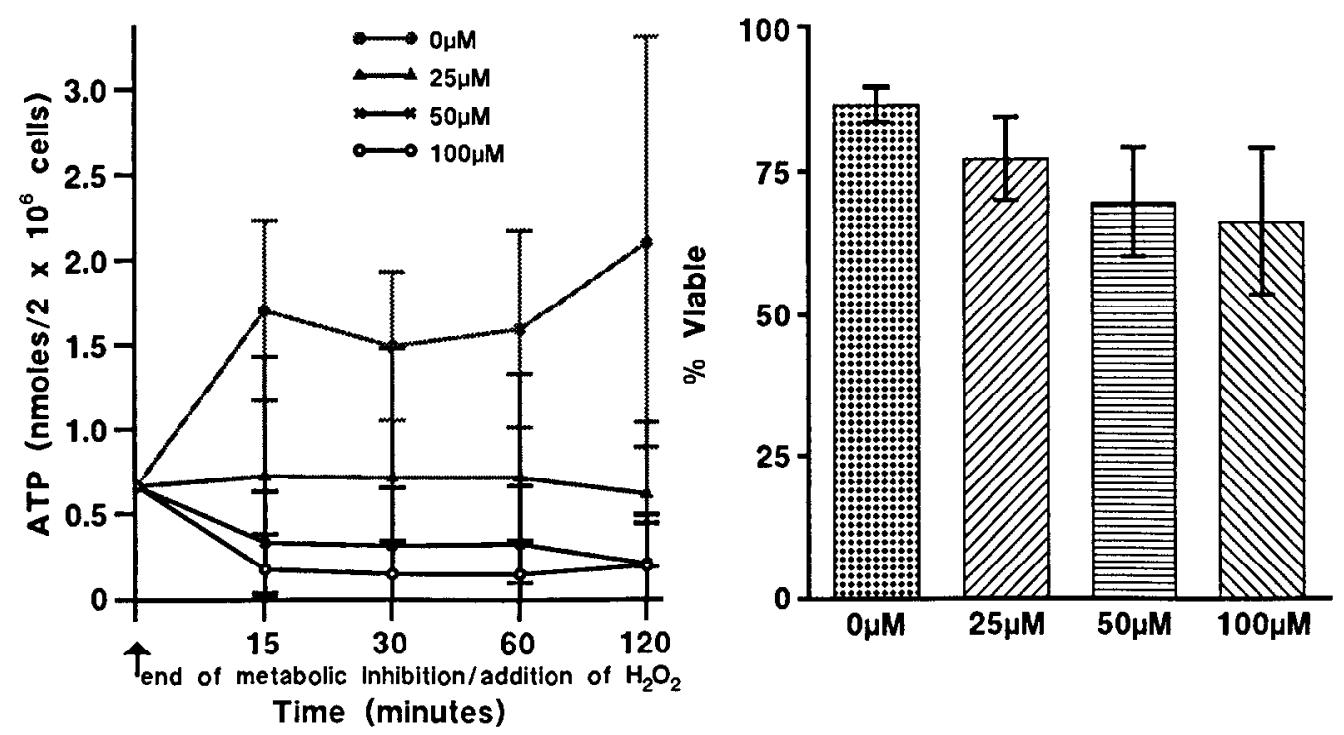

FIG. 2. ATP and cell viability data during $2 \mathrm{hr}$ after rescue from metabolic inhibition. Glucose deprivation and $650 \mathrm{n} M$ oligomycin were the conditions of metabolic inhibition. Significant differences $(P<0.05)$ are seen for ATP levels and cell viability between cells not exposed to oxidants and cells that were subjected to 25,50 , and $100 \mu M \mathrm{H}_{2} \mathrm{O}_{2}$. 

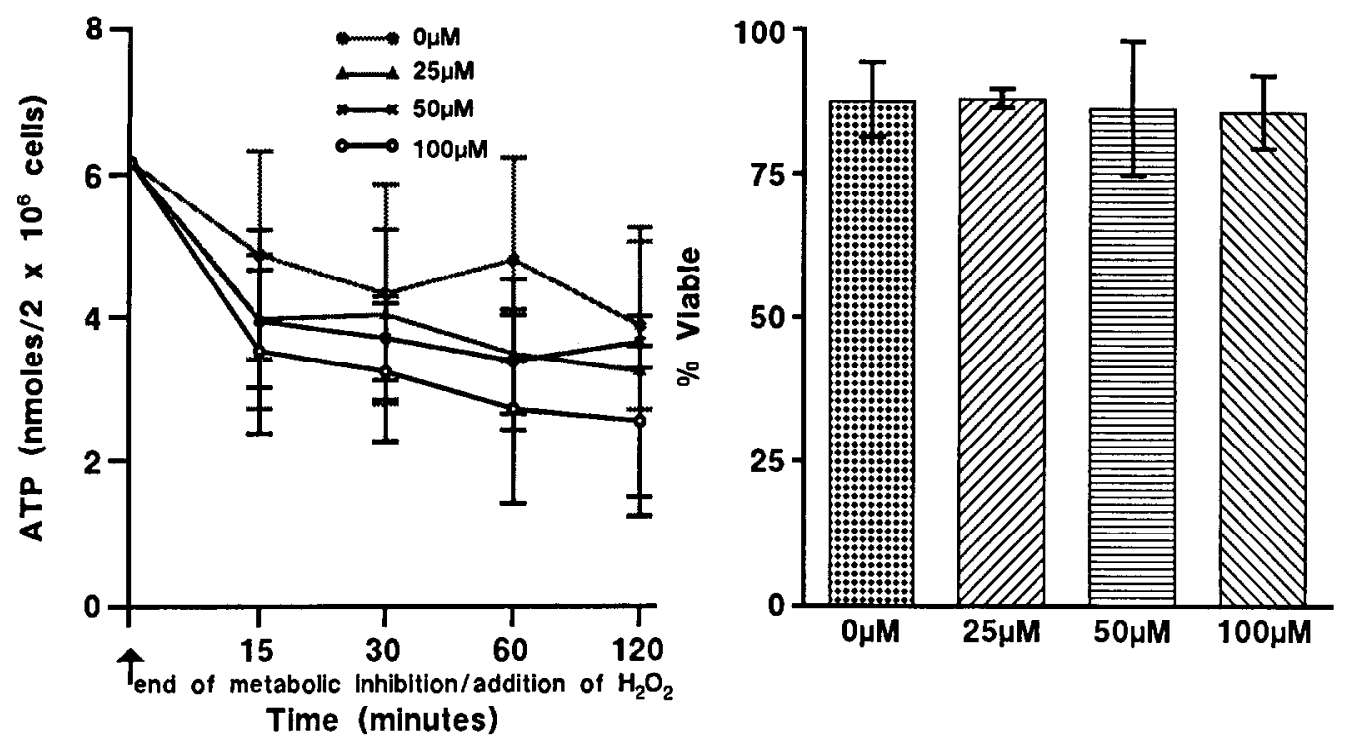

FIG. 3. ATP and cell viability data for cells that were exposed to $\mathrm{H}_{2} \mathrm{O}_{2}$ but were not metabolically inhibited. No significant differences in ATP levels or cell viability are apparent between cells that were exposed to oxidants and those that were not.

drial inhibition has been shown to cause intracellular acidosis [11], we examined changes in intracellular $\mathrm{pH}$ that were associated with the conditions in these experiments in which cells were exquisitely sensitive to oxidant injury. Metabolic inhibition with glucose depletion and oligomycin produced a rapid and significant $(P$ $<0.001$ ) drop in intracellular pH (Fig. 8). Mitochondrial inhibition with oligomycin alone also produced significant $(P<0.02)$ decreases in intracellular $\mathrm{pH}$ even as early as $15 \mathrm{~min}$, although not as marked as the cells also deprived of glucose. Substrate depletion and exposure to KCN similarly produced a rapid and significant drop ( $P$ $<0.01$ ) in intracellular $\mathrm{pH}$. In contrast, glucose depletion alone did not change intracellular $\mathrm{pH}$ over a 4 -hr time course. Intracellular acidosis correlated well with conditions associated with enhanced sensitivity to oxidants.

\section{Effect of Metabolic Inhibition on $\mathrm{H}_{2} \mathrm{O}_{2}$ Consumption}

The kinetics of $\mathrm{H}_{2} \mathrm{O}_{2}$ consumption, which is a reflection of the $\mathrm{H}_{2} \mathrm{O}_{2}$ scavenging capability of the cell, was examined to determine if $\mathrm{H}_{2} \mathrm{O}_{2}$ scavenging was affected by metabolic inhibition. There were no differences in the rate of $\mathrm{H}_{2} \mathrm{O}_{2}$ consumption between control cells and cells metabolically inhibited for $2 \mathrm{hr}$ with glucose depletion and $650 \mathrm{nM}$ oligomycin (Fig. 9). Inhibition of catalase activity by incubating control cells for $1 \mathrm{hr}$ with $12 \mathrm{mM}$
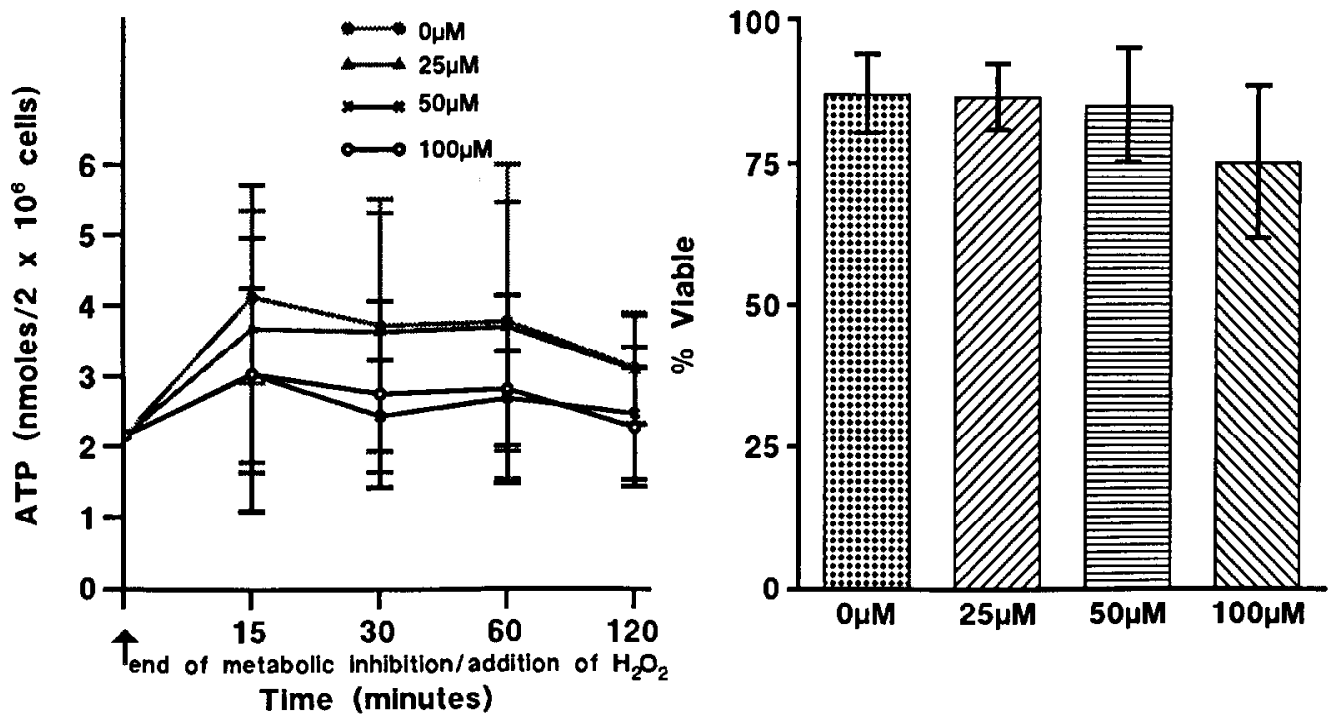

FIG. 4. ATP and cell viability data for cells that were deprived of glucose for $4 \mathrm{hr}$ before rescue and exposure to $\mathrm{H}_{2} \mathrm{O}_{2}$. No significant differences in ATP levels or cell viability are apparent between cells that were exposed to oxidants and those that were not. 

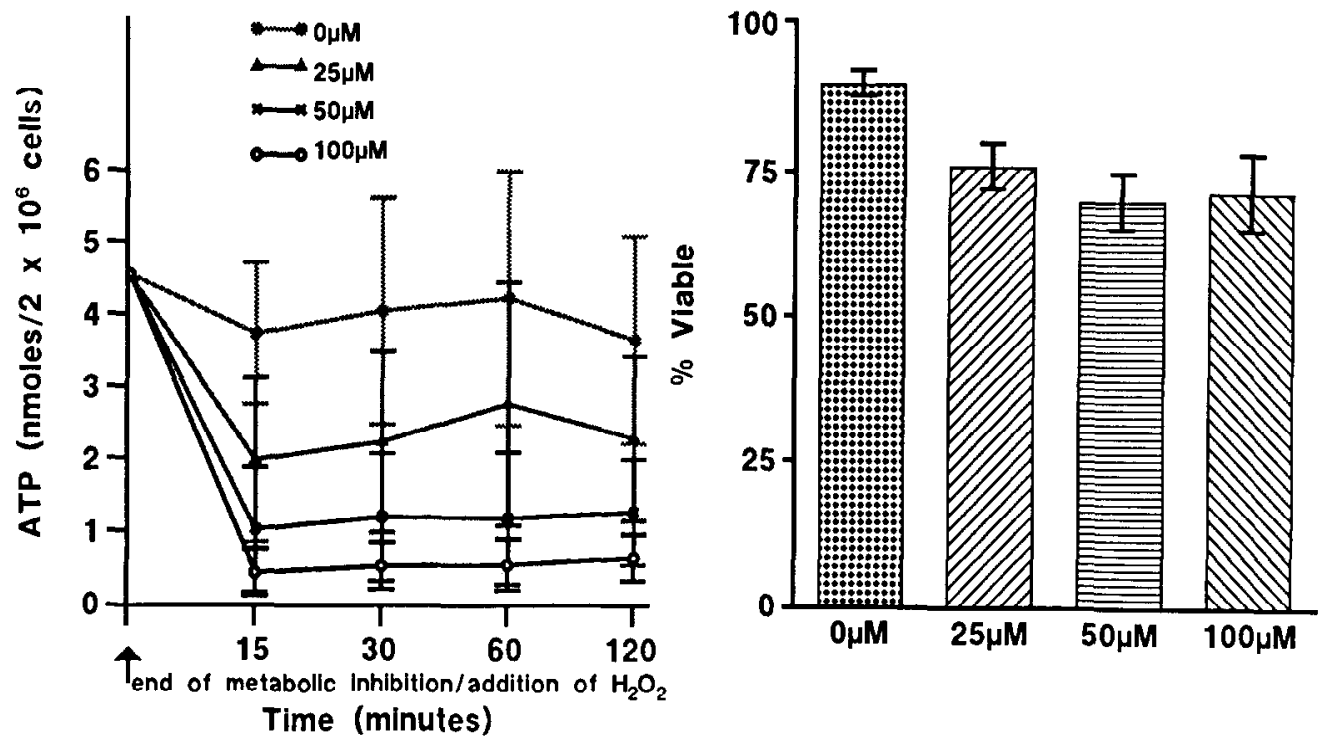

FIG. 5. ATP and cell viability dati for cells that were subjected to $2 \mathrm{hr}$ of mitochondrial inhibition alone with $650 \mathrm{nM}$ oligomycin before rescue and exposure to $\mathrm{H}_{2} \mathrm{O}_{2}$. Significant differences $(P<0.05)$ in ATP levels and cell viability were noted between cells exposed to $\mathrm{H}_{2} \mathrm{O}_{2}$ and those that were not.

aminotriazole [18] decreased the rate of $\mathrm{H}_{2} \mathrm{O}_{2}$ consumption by approximately $75 \%$, confirming the importance of this enzyme in metabolizing $\mathrm{H}_{2} \mathrm{O}_{2}$. These data suggest that metabolic inhibition does not affect catalase or other intracellular enzymes responsible for $\mathrm{H}_{2} \mathrm{O}_{2}$ catabolism.

\section{DISCUSSION}

The traditional hypothesis that ischemic injury can be reversed by restoration of blood flow has been challenged during the past decade by numerous studies which have shown that reperfusion of an ischemic organ is in itself damaging $[8,19]$. While some studies have suggested that normalization of $\mathrm{pH}$ in an ischemic cell may be damaging $[13,15]$, most research has concentrated on the role of oxidants in reperfusion injury [8, 20-22]. Current concepts of reperfusion injury actually invoke the interaction of two mechanisms of injury, namely, ischemia followed by oxidant attack. A wide range of cellular functions have been shown to be adversely affected by oxidants [1-6]. Ischemic conditions alone also have their own impact on cell function, including ATP depletion and intracellular acidosis [10]. It
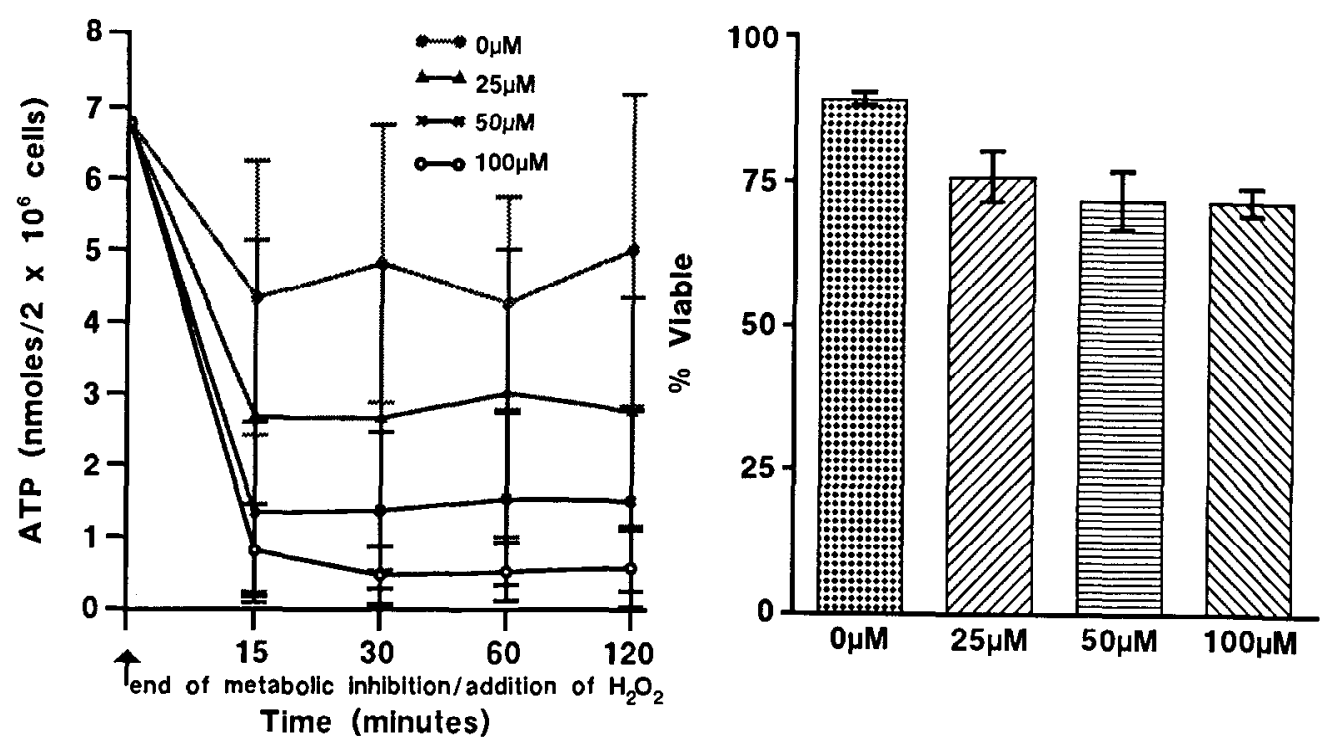

FIG. 6. ATP and cell viability data for cells that were subjected to $15 \mathrm{~min}$ of mitochondrial inhibition with $650 \mathrm{n} M$ oligomycin before rescue and exposure to $\mathrm{H}_{2} \mathrm{O}_{2}$. Significant differences $(P<0.05)$ in ATP levels and cell viability were noted between cells that were subjected to $\mathrm{H}_{2} \mathrm{O}_{2}$ at the time of rescue and those that were not. 

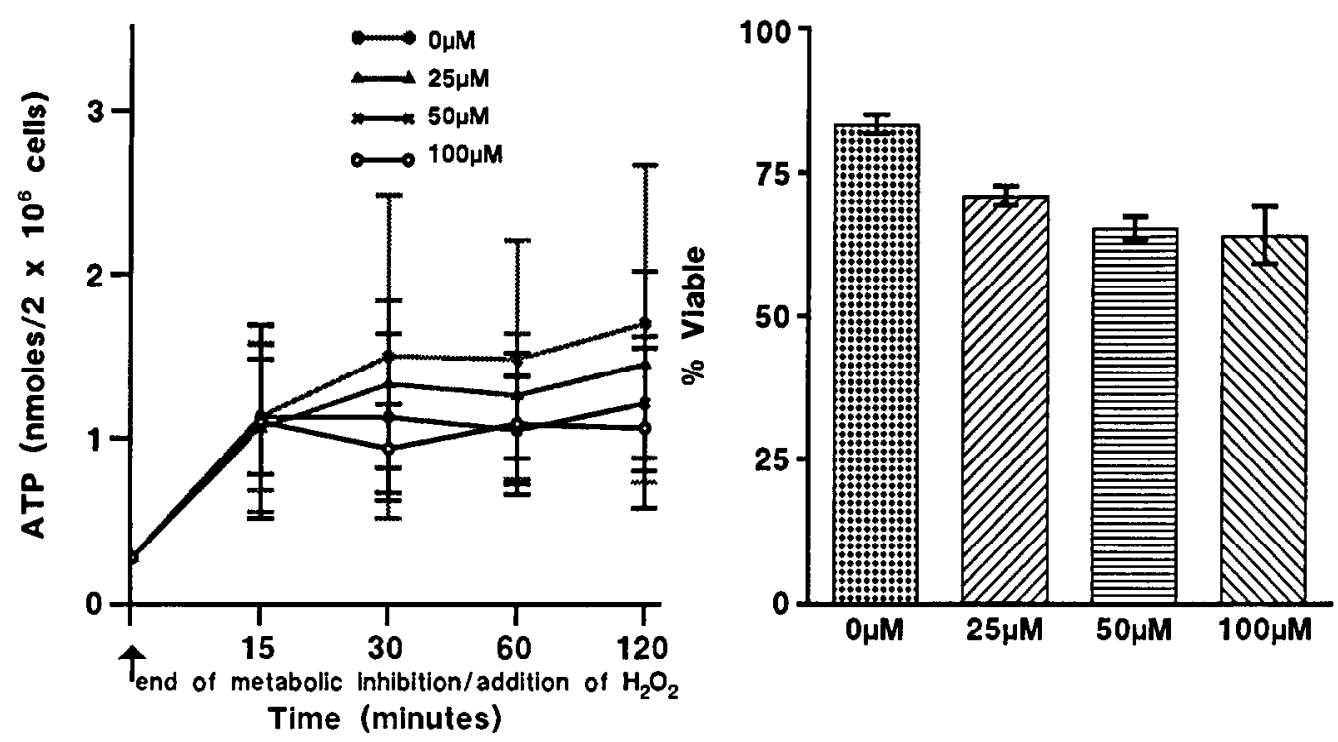

FIG. 7. ATP and cell viability data for cells that were metabolically inhibited for $2 \mathrm{hr}$ with glucose deprivation and $4 \mathrm{mM}$ KCN. ATP levels after injury with 25,50 , or $100 \mu M \mathrm{H}_{2} \mathrm{O}_{2}$ are not statistically different from those cells that were not exposed to $\mathrm{H}_{2} \mathrm{O}_{2}$. Cell viability was significantly different $(P<0.05)$ between the cells exposed to $\mathrm{H}_{2} \mathrm{O}_{2}$ and those that were not.

seems feasible that ischemia may compromise the ability of a cell or organ to weather an oxidant attack. It may also be possible that ischemia and oxidants synergistically injure cells because some manifestations of ischemic injury, such as ATP depletion, are also seen in oxidant injury. The purpose of this study, then, was to examine if a synergism exists between ischemia and oxidant injury and to possibly gain some insight into the mechanism of this potentiation.

The data in Fig. 1 show the consequences of metabolic inhibition on ATP levels. The chemical ischemia model using glucose deprivation and a mitochondrial inhibitor reliably produced significant drops in ATP levels by 2 hr. Cell viability was only marginally affected by this period of metabolic inhibition. In this study, rescue from metabolic inhibition was attempted by a wash step and subsequent addition of glucose. Although ATP levels usually improved after rescue from metabolic inhibition, they did not return to initial levels within the time frame of this experiment, regardless of the mitochondrial inhibitor used. The impaired ability of cells to replenish intracellular ATP levels may have been due to incomplete

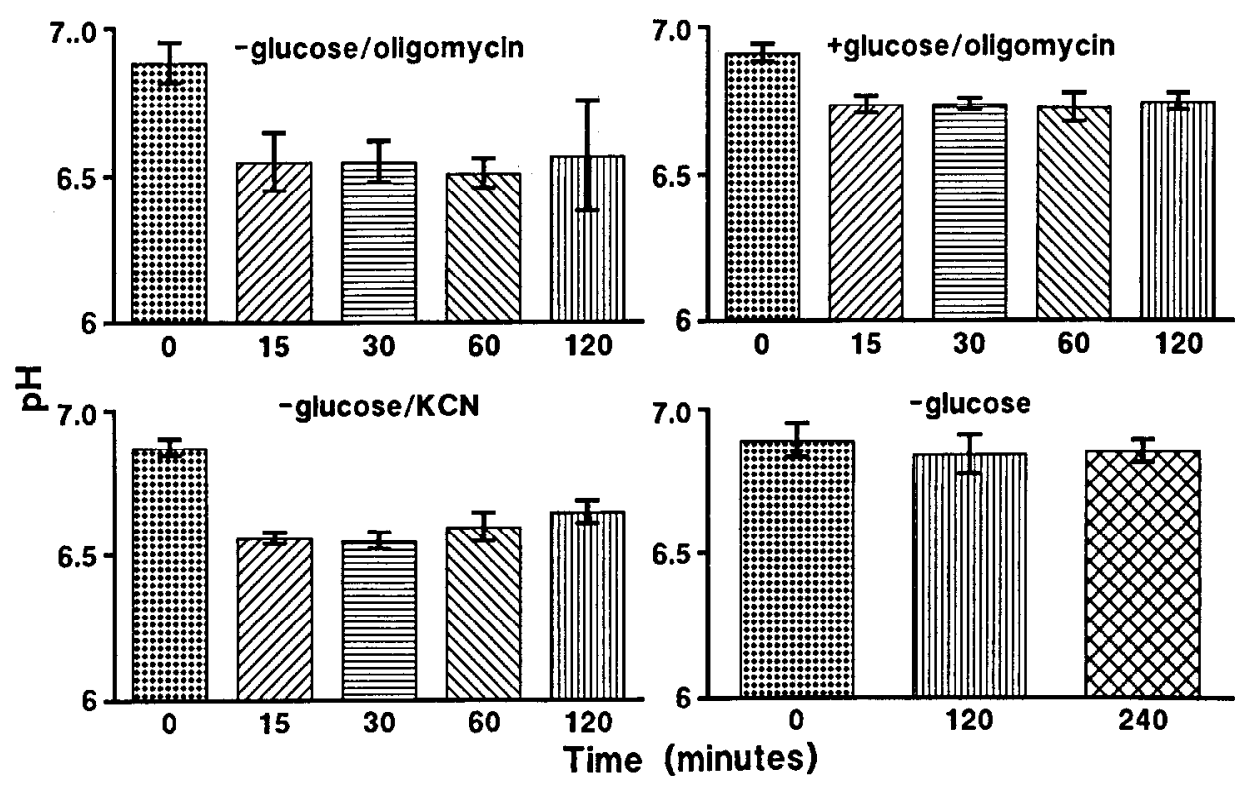

FIG. 8. Intracellular $\mathrm{pH}$ during different conditions of metabolic inhibition. Statistically significant differences $(P<0.05)$ were seen between initial $\mathrm{pH}$ values and those measured during subsequent metabolic inhibition except for cells that were subjected to glucose deprivation alone. 
$1 \mathrm{mM} \mathrm{H} \mathrm{O}_{2}$

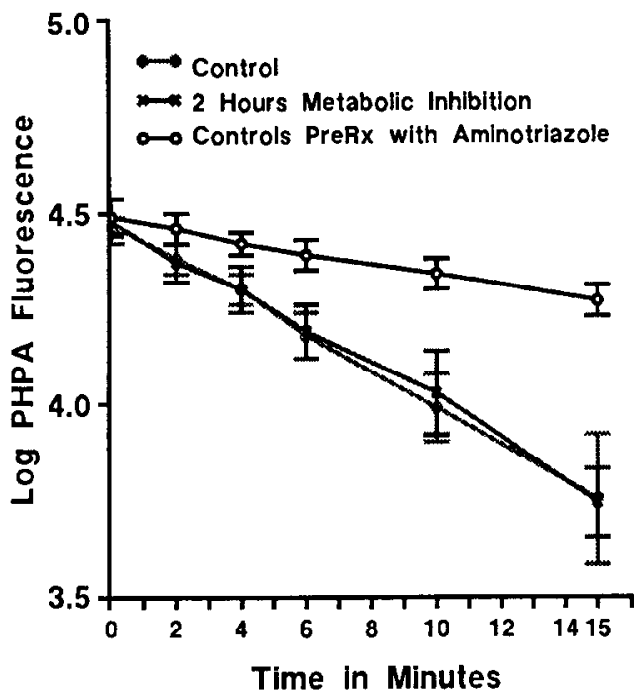

$5 \mathrm{mM} \mathrm{H}_{2} \mathrm{O}_{2}$

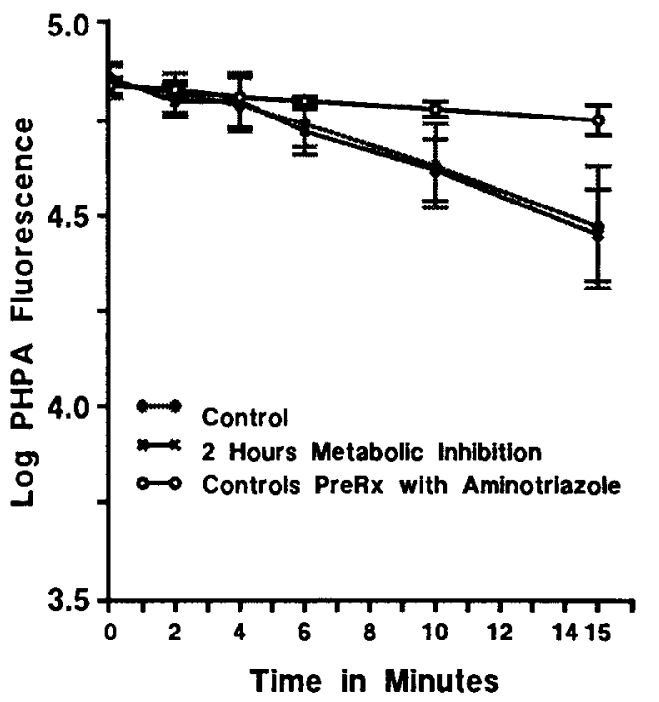

FIG. 9. Rate of $\mathrm{H}_{2} \mathrm{O}_{2}$ consumption over 15 min for cells exposed to 1 or $5 \mathrm{mM} \mathrm{H}_{2} \mathrm{O}_{2}$. The rate of $\mathrm{H}_{2} \mathrm{O}_{2}$ consumption by metabolically inhibited cells was not different from control cells. Pretreatment of control cells with $12 \mathrm{mM}$ aminotriazole (an inhibitor of catalase activity) for $1 \mathrm{hr}$ prior to exposure to $\mathrm{H}_{2} \mathrm{O}_{2}$ reduced the rate of $\mathrm{H}_{2} \mathrm{O}_{2}$ consumption by approximately $75 \% . \mathrm{H}_{2} \mathrm{O}_{2}$ added to buffer without cells did not demonstrate any deterioration of fluorescence during a 15-min time period (data not shown).

relief of mitochondrial inhibition after the wash step. However, cells subjected to simple glucose depletion did not fully recover their ATP levels after rescue from glucose deprivation, suggesting that substrate depletion in itself prevented subsequent restoration of ATP levels. Despite the observations that ATP levels were not fully restored after relief of metabolic inhibition, cell viability was not affected during the time course of rescue from metabolic inhibition, suggesting that the ATP levels present, while lower than initial values, were sufficient to maintain vital cell functions.

Cells subjected to $2 \mathrm{hr}$ of glucose deprivation and mitochondrial inhibition with oligomycin were exquisitely sensitive to oxidants introduced at the time of rescue from metabolic inhibition. Both ATP regeneration and cell viability were adversely affected. The consequences of exposure to the same concentrations of $\mathrm{H}_{2} \mathrm{O}_{2}$ in cells not subjected to metabolic inhibition were minimal, with no significant changes in ATP levels or cell viability. These observations suggested that a synergism existed between injury from metabolic inhibition and oxidant injury.

To determine whether substrate depletion or mitochondrial inhibition was more critical to this synergism, a series of experiments were performed with one or the other condition. Cells subjected to substrate depletion alone prior to oxidant injury at the time of rescue from glucose depletion did not demonstrate any effect on ATP synthesis or cell viability beyond that seen with substrate depletion without oxidant exposure. In contrast, cells subjected to $2 \mathrm{hr}$ of mitochondrial inhibition alone did show a synergistic effect between oxidant exposure and mitochondrial inhibition. Either condition alone $(2 \mathrm{hr}$ of mitochondrial inhibition or $4 \mathrm{hr}$ of glucose depletion) produced comparable reductions in ATP levels, but only the mitochondrial inhibition was associated with synergism. The contrasting outcomes in response to oxidant exposure suggested that ATP levels at the time of oxidant challenge were probably not a determinant of sensitivity to oxidant injury. In further experiments, brief periods of mitochondrial inhibition alone produced no significant changes in intracellular ATP during metabolic inhibition. Significant changes in cell viability in response to low concentrations of oxidants following the brief exposure to oligomycin lend further support to the hypothesis that mitochondrial inhibition renders cells vulnerable to an oxidant attack and the effect is independent of the level of ATP within the cells at the time of oxidant injury.

To ensure that these findings were not specific to oligomycin, another mitochondrial inhibitor, $\mathrm{KCN}$, was used. $\mathrm{KCN}$, which inhibits electron transport by binding to cytochrome oxidase [23], inhibits mitochondrial function at a different site than oligomycin, which inhibits the Fo ATPase-synthase complex on the inner mitochondrial membrane [1]. The finding that restoration of ATP levels after rescue from mitochondrial inhibition with KCN was unaffected by the addition of oxidants at the time of rescue was in contrast to that seen with oligomycin. However, cell viability was adversely affected by either inhibitor when followed by oxidant exposure. These results imply that the lethal injury which is potentiated under these conditions is not dependent on altered levels of intracellular ATP.

The observation that intracellular acidosis coincides with conditions in which cells are vulnerable to oxidants suggests that intracellular acidosis may sensitize cells to oxidant attack. It is unclear at this time whether the 
intracellular acidosis is simply a herald of mitochondrial inhibition or whether the acidosis itself is what potentiates oxidant injury. Ischemia probably leads to intracellular acidosis by several pathways, including accumulation of lactic acid and hydrolysis of nucleoside phosphates (ATP $\left.+\mathrm{H}_{2} \mathrm{O}=\mathrm{H}^{+}+\mathrm{P}_{\mathrm{i}}+\mathrm{ADP}\right)[10]$. Acid loads which exceed intracellular buffering capacity can have several effects on cellular function, including ion shifts and changes in enzyme activity [24].

Metabolic inhibition with glucose deprivation and oligomycin did not change the rate of $\mathrm{H}_{2} \mathrm{O}_{2}$ consumption. Since glucose depletion and oligomycin have been shown to cause intracellular acidosis, it can be inferred that the activity of these $\mathrm{H}_{2} \mathrm{O}_{2}$ scavengers is not affected by the changes in $\mathrm{pH}$ which are seen during metabolic inhibition. Thus, the potentiation of $\mathrm{H}_{2} \mathrm{O}_{2}$ injury by prior metabolic inhibition cannot be accounted for on the basis of altered $\mathrm{H}_{2} \mathrm{O}_{2}$ scavenging activity.

In conclusion it appears that metabolic inhibition leads to increased susceptibility to concentrations of $\mathrm{H}_{2} \mathrm{O}_{2}$ which usually do not produce short-term injury in endothelial cells. The potentiation of oxidant injury is dependent on inhibition of mitochondrial function and is independent of ATP levels within the cell. Intracellular acidosis may be a mechanism by which oxidant injury is potentiated, but further studies are needed to confirm this premise.

\section{ACKNOWLEDGMENTS}

This work was supported in part by a Merit Review Grant from the Department of Veterans Affairs and also by a grant from Lilly Research Laboratories (Indianapolis, IN).

\section{REFERENCES}

1. Hyslop, P. A., Hinshaw, D. B., Halsey, W. A., Jr., Schrauffstatter, I. U., Sauerheber, R. D., Spragg, R. G., Jackson, J. H., and Cochrane, C. G. Mechanisms of oxidant mediated injury: The glycolytic and mitochondrial pathways of ADP phosphorylation are major intracellular targets inactivated by hydrogen peroxide. J. Biol. Chem. 263: 1665, 1988.

2. Spragg, R. G., Hinshaw, D. B., Hyslop, P. A., Schraufstatter, I. U., and Cochrane, C. G. Alterations in adenosine triphosphate and energy charge in cultured endothelial and $\mathrm{P} 388 \mathrm{D}_{1}$ cells after oxidant injury. J. Clin. Invest. 76: 1471, 1985.

3. Jackson, J. H., Gajewski, E., Schraufstatter, I. U., Hyslop, P. A., Fuciarelli, A. F., Cochrane, C. G., and Dizdaroglu, M. Damage to the bases in DNA induced by stimulated human neutrophils. $J$. Clin. Invest. 84: 1644, 1989.

4. Schraufstatter, I. U., Hinshaw, D. B., Hyslop, P. A., Spragg, R. G., and Cochrane, C. G. Oxidant injury of cells: DNA strand breaks activate polyadenosine diphosphate-ribose polymerase and lead to depletion of nicotinamide adenine dinucleotide. $J$. Clin. Invest. 77: 1312, 1986.

5. Hinshaw, D. B., Burger, J. M., Armstrong, B. C., and Hyslop,
P. A. Mechanism of endothelial cell shape change in oxidant injury. J. Surg. Res. 46: 339, 1989.

6. Hyslop, P. A., Hinshaw, D. B., Scraufstatter, I. U., Sklar, L. A., Spragg, R. G., and Cochrane, C. G. Intracellular calcium homeostasis during hydrogen peroxide injury to cultured $\mathrm{P} 388 \mathrm{D}_{1}$ cells. J. Cell. Physiol. 129: 356, 1986.

7. Weiss, S. J., Young, J., LoBuglio, A. F., Slivka, A., and Nimeh, N. F. Role of hydrogen peroxide in neutrophil-mediated destruction of cultured endothelial cells. J. Clin. Invest. 68: 714, 1981.

8. McCord, J. M. Oxygen-derived free radicals in postischemic tissue injury. N. Engl. J. Med. 312: 159, 1985.

9. Hinshaw, D. B., Burger, J. M., Delius, R. E., and Hyslop, P. A. Mechanism of protection of oxidant-injured endothelial cells by glutamine. Surgery 108: 298, 1990.

10. Gores, G. J., Niemann, A. L., Wray, B. E., Herman, B., and Lemasters, J. J. Intracellular pH during "chemical ischemia" in cultured rat hepatocytes. Protection by intracellular acidosis against the onset of cell death. J. Clin. Invest. 83: 386, 1989.

11. Hinshaw, D. B., Armstrong, B. A., Beals, T. F., and Hyslop, P. A. A cellular model of endothelial cell ischemia. $J$. Surg. Res. 44: $527,1988$.

12. Snowdowne, K. W., Freudenrich, C. C., and Borle, A. B. The effects of anoxia on cytosolic free calcium, calcium fluxes, and cellular ATP levels in cultured kidney cells. J. Biol. Chem. 260: 11619, 1985.

13. Bonventre, J. V., and Cheung, J. Y. Effects of metabolic acidosis on viability of cells exposed to anoxia. Am. J. Physiol. 249: C149, 1985.

14. Ferrari, R., Ceconi, C., Curello, S., Guanieri, C., Caldarera, C. M., Albertini, A., and Visioli, O. Oxygen mediated myocardial damage during ischaemia and reperfusion: Role of cellular defenses against oxygen toxicity. J. Mol. Cell. Cardiol. 17: 937, 1985.

15. Gores, G. J., Niemann, A. C., Fleishmann, K. E., Dawson, T. L., Herman, B., and Lemasters, J. J. Extracellular acidosis delays onset of cell death in ATP depleted hepatocytes. Am. J. Physiol. 255: C315, 1988.

16. Stanley, P. E., and Williams, S. G. Use of the liquid scintillation spectrometer for determing adenosine triphosphate by the luciferase enzyme. Anal. Biochem. 29: 281, 1969.

17. Hyslop, P. A., and Sklar, L. A. A quantitative fluorimetric assay for the determination of oxidant production by polymorphonuclear leukocytes: Its use in the simultaneous fluorimetric assay of cellular activation processes. Anal. Biochem. 141: 280, 1984.

18. Schraufstatter, I. U., Hyslop, P. A., Jackson, J. H., and Cochrane, C. G. Oxidant-induced DNA damage of target cells. J. Clin. Invest. 82: 1040, 1988.

19. Braunwald, E., and Kloner, R. A. Myocardial reperfusion: A double-edged sword? J. Clin. Invest. 76: 1713, 1985.

20. Engler, R., and Covell, J. W. Granulocytes cause reperfusion ventricular dysfunction after 15 minute ischemia in the dog. Circ. Res. 61: 20, 1987.

21. Forman, M. B., Puett, D. W., and Virmani, R. Endothelial and myocardial injury during ischemia and reperfusion: Pathogenesis and therapeutic implications. J. Am. Coll. Cardiol. 13: 450, 1989.

22. Granger, D. N. Role of xanthine oxidase and granulocytes in ischemia-reperfusion injury. Am. J. Physiol. 255: H1269, 1988.

23. Stryer, L. Biochemistry, 3rd ed. New York: Freeman, 1988.

24. Swallow, C. J., Grinstein, S., Sudsbury, R. A., and Rotstein, O. D. Modulation of the macrophage respiratory burst by an acidic environment: The critical role of cytoplasmic $\mathrm{pH}$ regulation by proton extrusion pumps. Surgery 108: 363, 1990. 